\section{Prospects power up for nuclear energy}

American energy utility NRG Energy is planning to build two reactors for nuclear power in Texas. Its application to the US Nuclear Regulatory Commission for permission to construct the reactors marks the first such request in the United States for three decades.

Meanwhile, Italy is reversing a 20-year post-Chernobyl moratorium on nuclear fission research to participate in the scientific development of 'Generation IV' nuclear reactors. How exactly the country will contribute to the Generation IV research has not yet been revealed. The planned next generation of nuclear power plants is intended to improve nuclear safety and to minimize waste and natural-resource use compared with the current generation of plants.

\section{Europe plots course for funding navigation system}

The European Commission is launching a bid to save Galileo, the continent's troubled satellite navigation system. It has asked the European Parliament to back its plan to foot the whole bill for the 30-satellite system. The cost would be some $€ 3$.4 billion (US $\$ 4.8$ billion) over the next six years.

Galileo would see Europe break free from its dependence on the US-based Global Positioning System (GPS). But the project suffered a serious setback earlier this year when a public-private deal to fund the system collapsed (see Nature 447, 765; 2007).

If the commission manages to salvage Galileo, it would get the extra cash from surplus monies in the agricultural and administration budgets. Member states will take the first steps to making a decision on the proposals in early October.

Meanwhile, President George W. Bush has announced that the United States 䍃 will permanently leave the capability

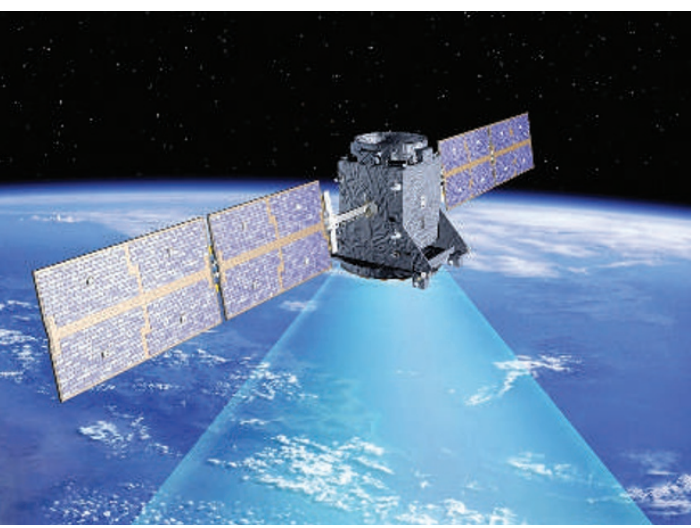

Up in the air: Europe's planned Galileo navigation system has yet to secure full funding.

\title{
Meteorite proves to be a hit in Peru
}

Researchers are examining a

17-metre-wide crater in southern

Peru, looking for fragments of

what is believed to be one of the

largest meteorites to hit land

in years.

The meteorite apparently

plummeted to Earth on

15 September near the village of

Carancas, west of Lake Titicaca

on the Bolivian border. Scientists

from Peru's Geological, Mining

and Metallurgical Institute in

Lima last week checked the crater

(pictured), now filled with water,

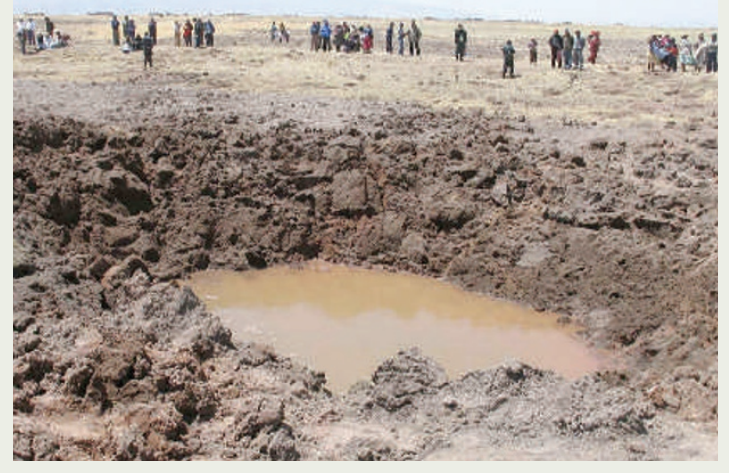

for debris from the object they described as a chondrite or stony meteorite.

People living near the impact complained of odd smells and illnesses, but some scientists

speculated that the reported sickness may be group hysteria. They noted that objects that come from the sky have deep cultural significance to villagers.

of distorting signals off any future GPS satellites. This feature was designed to give the US government a better working version of GPS than civilians, but has not been used since 2000 .

\section{HIV vaccine failure prompts Merck to halt trial}

An HIV vaccine being developed by Merck has apparently failed, causing the company to halt a large and once-promising clinical trial last week.

Merck's STEP vaccine used a mixture of components from three weakened adenoviruses to carry three synthetically produced HIV genes. The hope was that each gene would stimulate an immune response against the virus, as earlier trials had suggested.

The latest trial began in 2004 and enrolled 3,000 people considered to be at high risk of infection. But a group of 741 volunteers who received the vaccine saw $24 \mathrm{HIV}$ infections, compared with the control group of 762 people who saw 21 infections. Furthermore, the vaccine did not reduce the amount of HIV in the bloodstream of those infected.

\section{FDA poised for broader powers over drugs on sale}

The US Congress last week passed a bill significantly increasing the powers of the Food and Drug Administration (FDA) to police the safety of marketed drugs (see Nature 446, 844-845; 2007). President George W. Bush is expected to sign the bill by 30 September, when a current law expires.

Under the new law, the FDA will for the first time be able to order companies to make label changes on marketed drugs; to run new clinical trials when safety issues emerge; and to fine noncompliant companies up to $\$ 10$ million. It also includes $\$ 225$ million in new drugcompany-paid user fees that the agency will spend on post-market drug safety.

The bill requires the FDA to cut by $25 \%$ the number of waivers it grants to external experts with financial interests in matters on which they are advising the agency. Such waivers allow them to serve on committees that advise the agency on drug approvals, withdrawals and label changes - advice it almost always follows.

\section{California universities maintain tobacco habit}

Under a policy adopted last week, scientists at the University of California's ten campuses can continue to accept research grants from tobacco firms. But new grants coming from the industry will undergo added scrutiny.

The University of California's governing board approved the policy on 20 September after several years of intense debate - spurred by a core of outraged scientists (see Nature 446, 242; 2007). Under the new policy, proposed tobacco-firm grants will undergo peer review by panels of scholars at each campus, where the chancellors will oversee the monitoring process. There will also be an annual report on all research funded by the tobacco industry, describing both submitted and approved projects.

Last year, seven of the university's campuses received a total of $\$ 16$ million for 23 projects, all funded by Philip Morris of Richmond, Virginia.

\section{Correction}

The Editorial 'Epo, by any other name' (Nature 449,$259 ; 2007$ ) incorrectly stated that the drug Cerezyme is produced by Genentech. It is, in fact, produced by Genzyme Therapeutics. 